\title{
Anthelmintic Efficacy of Ethanol Extract of Raw Kepok Banana Peel (Musa paradisiaca L.) Against Ascaridia galli Worms In Vitro
}

\author{
${ }^{1)}$ Annastasya Yuliani Rahayu, ${ }^{2)}$ Retno Sri Wahjuni, ${ }^{2)}$ Dewa Ketut Meles, ${ }^{3)}$ Retno Wulansari \\ ${ }^{1)}$ Student, Faculty of Veterinary Medicine, Universitas Airlangga, atsyulianioo7@gmail.com \\ ${ }^{2)}$ Division of Basic Veterinary Medicine, Faculty of Veterinary Medicine, Universitas Airlangga \\ ${ }^{3)}$ Veterinary Internal Medicine Division, Department of Clinic, Reproduction and Pathology, Faculty of \\ Veterinary Medicine, IPB University \\ Corresponding author: retno-s-w@fkh.unair.ac.id
}

\begin{abstract}
The aims of this study was to know anthelmintic efficacy through determine the concentration, duration, and interaction between concentration and duration of raw kepok banana peel ethanol extract against mortality rate of Ascaridia galli using in vitro method. Present study was used completely randomized design. This method of this study was used a total of 600 samples of Ascaridia galli with length of 7-11 cm without differentiating their sex. The concentration of raw kepok banana peel ethanol extract was divided into $25 \%, 50 \%$ and $75 \%$. Physiological saline solution and piperazine citrate $10 \mathrm{mg} / \mathrm{ml}$ were being used as negative and positive control. Each treatment then being replicated six times. The recording of mortality rate was done at 2, 4, 6, 8 and 10 hours of observation. Ascaridia galli was confirmed death if there was no movement while triggered by anatomy tweezers and dipped in slightly warm water $\left(50^{\circ} \mathrm{C}\right)$. The data obtained was analyzed using ANOVA factorial and continued with Duncan Multiple Range Test by SPSS 26 for Windows. The results were showed that in $75 \%$ concentration and 10 hours of treatment can cause the highest mortality rate against Ascaridia galli. Interaction between concentration and duration of treatment reveals that $75 \%$ concentration of raw kepok banana peel ethanol extract in 10 hours of observation was recorded causing the highest mortality rate against Ascaridia galli.
\end{abstract}

Keywords: Ascaridia galli, ethanol extract, kapok, banana peel, in vitro, Musa paradisiaca

\section{Introduction}

Currently in developing country such as Indonesia, domestic chicken farming play important role for the economic development among community (Hidayat, 2012). The prospect of domestic chicken farming has a promising opportunity in the future, considering that the demand for poultry meat and poultry eggs were continues to increase in accordance with the increase of income, as well as public knowledge regarding fulfilling nutrition in order to increase the need of animal protein for families (Pabala, 2016).

In the development of domestic chicken farming there are several factors that can affect production, one of which is a disease caused by parasites. Ascaridia galli (A. galli) infection can cause significant economic loss every year. Chickens with naturally infected or artificially infected with this parasite possibly have abnormal growth and decreased body weight gain (Zalizar and Rahayu, 2001; Soulsby, 1986) as well as decreased in total egg production (Zalizar and Satrija 2009).

The effective control measure for worm infection is to combine good livestock management and the provision of anthelmintics in order to eliminate the parasitic worms from the internal organs of livestock (Istyan, 2015). According to Ahmad (2014), controlling worm infection by using synthetic anthelmintic treatment for livestock will cause a negative impact such as drug resistance and the high price of the drug which is not affordable for local farmers. Previous studies have shown that $A$. galli was resistant to specific anthelmintics such as benzimidazole, imidothiazoletetrahydropyrine and macrocyclic lactones (Max et al., 2002; Kaplan, 2004). This drug resistance is caused by incomplete treatment with the prescribed dose and withdrawal time (Butaye et al., 2003; Ozaraga et al., 2015). The increasing incidence of resistance and the increasing of consumer awareness of animal products that are wanted to free from drug residues, become a 
new approach on new anthelmintics research (Mubarokah et al., 2019).

Currently, many people are returning to using herbal plants as an alternative treatment for infectious disease. The advantage of herbal medicine lies in the principle which using natural compounds, so that the negative side effects can be minimized (Wulandari, 2016).

In Indonesia, there are more than 20,000 types of herbal plants, but only 1000 species were known through valid data and only about 300 species had been used in medicine aspect (Wulandari, 2016). One of the many types of herbal plants which easily found in Indonesia is the banana plant. Utilization of bananas is not only as food but also can be used as a treatment for certain disease. A part of the banana plant that can be used as a treatment is banana peel.

The kepok banana peel contains alkaloids, saponins, flavonoids and tannins (Hasma and Winda, 2019), which weel known that these compounds can act as anthelmintics. Saponins are active compounds that inhibit the mechanism of cholinesterase, so that the worms will experience spastic muscle paralysis and eventually lead to death (Alaydrus, 2016). Plants containing tannins are also known to have anthelmintic effects (Ningsih et al., 2013). Tannins can damage the cell membranes, causing worms to paralyze and the death occurs (Tiwow et al., 2013). Pappa et al. (2019) stated that tannin compounds were able to dissolve proteins in nematode eggshells, causing failure of embryo development, unhatching of eggs due to damage in sheath proteins, especially in earlyphase eggs that had not yet formed nematode larvae. The content of tannin is higher in the skin of unripe bananas (Djunaidi et al., 2014). Banana fruit contains an average of $11.21 \%$ flavonoids and $24.6 \%$ in banana peel (Dinastutie et al, 2015).

Ethanol extract of raw kepok banana peel is expected to be an alternative treatment for ascaridiasis based on herbs so that the risk of resistance can be minimized. Based on the description above, it can be used as a basis for researching the anthelmintic potency of ethanol extract of raw kepok banana peel (Musa paradisiaca L.) against $A$. galli using in vitro.

\section{Materials and Methods}

This study was a completely randomized factorial design was applied. This study was used A. galli worms obtained from the small intestine of native chickens at Wonokromo Market, Surabaya City. Total of 600 samples of A. galli with length of 7-11 $\mathrm{cm}$ without differentiating their sex. The concentration of raw kepok banana peel ethanol extract was divided into $25 \%, 50 \%$ and $75 \%$. Physiological saline solution and piperazine citrate $10 \mathrm{mg} / \mathrm{ml}$ were being used as negative and positive control. Each treatment then being replicated six times. The recording of mortality rate was done at 2, 4, 6, 8 and 10 hours of observation. Ascaridia galli was confirmed death if there was no movement while triggered by anatomy tweezers and dipped in slightly warm water $\left(50^{\circ} \mathrm{C}\right)$.

The data obtained were analyzed by factorial ANOVA transformed by $\sqrt{ } \mathrm{y} \%$ and followed by $5 \%$ Duncan's Multiple Range Test to determine whether there was an effect of the given treatment and to determine the significant effect of one treatment with another. Statistical analysis was done using Statistical Program Service and Solution (SPSS) version 26.

\section{Results and Discussion}

The mortality of $A$. galli were recorded every 2 hours, 4 hours, 6 hours, 8 hours and 10 hours. Based on results, the duration of dipping treatment has effect on mortality of $A$. galli proven by the highest mortality rate was recorded in 10 hours.

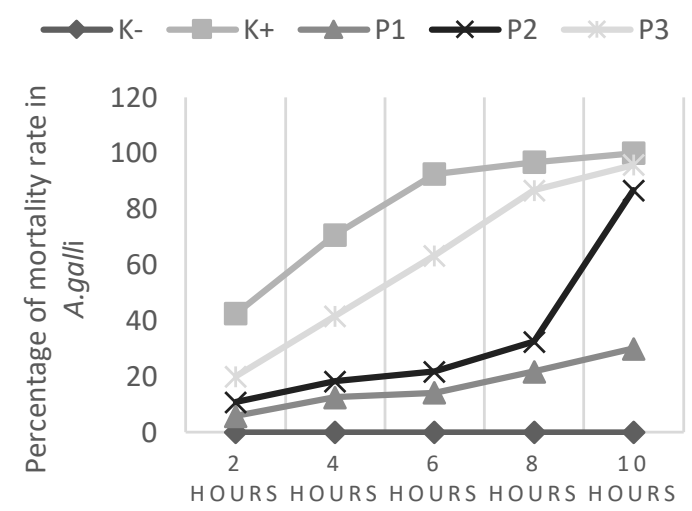

Figure 1. Graphic of the mortality rate of A. galli in various treatment and duration.

\section{The effect of various dose of treatment}

The results of the treatment group with the ethanol extract of raw kepok banana peel showed that the mortality of $A$. galli was significantly different between treatments. The mortality rate of $A$. galli was recorded higher in the higher dose of treatment. Treatment of $75 \%$ raw kepok banana peel ethanol extract was recorded as the most effective dose compared to the other treatments. 
Table 1. The effect of treatments against mortality rate of $A$. galli

\begin{tabular}{cc}
\hline Treatments & Mean \pm SD \\
\hline $\mathrm{K}-$ & $0.02^{\mathrm{a}} \pm 0.00$ \\
$\mathrm{P}_{1}$ & $0.37^{\mathrm{b}} \pm 0.18$ \\
$\mathrm{P}_{2}$ & $0.48^{\mathrm{c}} \pm 0.15$ \\
$\mathrm{P}_{3}$ & $0.75^{\mathrm{d}} \pm 0.23$ \\
$\mathrm{~K}+$ & $0.87^{\mathrm{e}} \pm 0.21$ \\
\hline
\end{tabular}

a,b,c,d,e Different superscript shows significant difference in statistical analysis $(\mathrm{p}<0.05)$.

\section{The effect of duration of treatment}

The mortality of $A$. galli was already recorded in 2 hours and increase every 2 hours of observation. The highest mortality rate was recorded in 10 hours of treatment.

Table 2 The effect of duration against mortality of A. galli

\begin{tabular}{cc}
\hline Waktu & Mean \pm SD \\
\hline 2 hours & $0.30^{\mathrm{a}} \pm 0.25$ \\
4 hours & $0.44^{\mathrm{b}} \pm 0.30$ \\
6 hours & $0.53^{\mathrm{c}} \pm 0.34$ \\
8 hours & $0.58^{\mathrm{cd}} \pm 0.36$ \\
10 hours & $0.63^{\mathrm{d}} \pm 0.37$ \\
\hline $\mathrm{a}, \mathrm{b}, \mathrm{c}, \mathrm{d}$ Different & superscript shows significant \\
difference in statistical analysis $(\mathrm{p}<0.05)$.
\end{tabular}

\section{The interaction between treatment and duration}

Based on the results, raw kapok banana peel was recorded have anthelmintic mechanism against A. galli in 2 hours of treatment. Moreover, the mortality rate of $A$. galli was increase in accordance with the addition hours and also significantly increase every 2 hours of treatment.

The interaction between various dose of treatment and duration using raw kapok banana peel have significant effect against the mortality rate of A. galli. The higher dose and duration of treatment was proven and recorded to be the cause of higher mortality rate.

According to Hasma and Winda (2019), it was found that the ethanol extract of raw kepok banana peel contains alkaloids, saponins, flavonoids and tannins which can act as anthelmintics. The extraction process serves to isolate secondary metabolites from the peel of the kepok banana. Suhendra et al. (2019) states that the basic principle of extraction is like dissolves like, where the solubility of a compound in a solvent is based on the similarity of polarity between the solvent and the extracted compound. Ethanol solvent was used in the extraction process because it can dissolve compounds from less polar to polar. One of the compounds that can be dissolved by ethanol is a phenolic compound. Ethanol can dissolve phenolic compounds because it is able to degrade cell walls so that bioactive compounds are more easily removed from plant cells.

Table 3 The interaction between treatment and duration against mortality rate of $A$. galli.

\begin{tabular}{|c|c|c|}
\hline Treatment & Duration & $\operatorname{Mean} \pm S D$ \\
\hline \multirow{5}{*}{ K- } & 2 hours & $0.02^{\mathrm{a}} \pm 0.00$ \\
\hline & 4 hours & $0.02^{\mathrm{a}} \pm 0.00$ \\
\hline & 6 hours & $0.02^{\mathrm{a}} \pm 0.00$ \\
\hline & 8 hours & $0.02^{a} \pm 0.00$ \\
\hline & 10 hours & $0.02^{a} \pm 0.00$ \\
\hline \multirow{5}{*}{$\mathrm{K}+$} & 2 hours & $0.58^{\mathrm{de}} \pm 0.31$ \\
\hline & 4 hours & $0.83^{f g} \pm 0.11$ \\
\hline & 6 hours & $0.96^{\mathrm{fgh}} \pm 0.05$ \\
\hline & 8 hours & $0.98^{\mathrm{gh}} \pm 0.03$ \\
\hline & 10 hours & $0.99^{h} \pm 0.00$ \\
\hline \multirow{5}{*}{ P1 } & 2 hours & $0.17^{\mathrm{a}} \pm 0.18$ \\
\hline & 4 hours & $0.33^{b} \pm 0.12$ \\
\hline & 6 hours & $0.41^{b c} \pm 0.12$ \\
\hline & 8 hours & $0.44^{b c d} \pm 0.15$ \\
\hline & 10 hours & $0.5^{2^{\text {cde }}} \pm 0.18$ \\
\hline \multirow{5}{*}{$\mathrm{P}_{2}$} & 2 hours & $0.32^{\mathrm{b}} \pm 0.06$ \\
\hline & 4 hours & $0.41^{b c} \pm 0.10$ \\
\hline & 6 hours & $0.45^{\mathrm{bcd}} \pm 0.11$ \\
\hline & 8 hours & $0.55^{\text {cde }} \pm 0.12$ \\
\hline & 10 hours & $0.66^{\mathrm{e}} \pm 0.11$ \\
\hline \multirow{5}{*}{$\mathrm{P}_{3}$} & 2 hours & $0.42^{\mathrm{bc}} \pm 0.16$ \\
\hline & 4 hours & $0.62^{\mathrm{e}} \pm 0.17$ \\
\hline & 6 hours & $0.81^{\mathrm{f}} \pm 0.07$ \\
\hline & 8 hours & $0.93^{\text {fgh }} \pm 0.02$ \\
\hline & 10 hours & $0.97^{\mathrm{gh}} \pm 0.01$ \\
\hline
\end{tabular}

$\overline{\mathrm{a}, \mathrm{b}, \mathrm{c}, \mathrm{d}, \mathrm{e}, \mathrm{fg}, \mathrm{h} \text { Different superscript shows significant }}$ difference in statistical analysis $(\mathrm{p}<0.05)$.

The anthelmintic effect of raw kepok banana peel ethanol extract was proven by observing the mortality of $A$. galli after being treated using in vitro measure. In the negative control, A. galli was immersed in physiological saline solution because in physiological saline did not have anthelmintic active compound (Meritha, 2019). Physiological saline solution can protect biological cells during the storage process because it is isotonic and can maintain not only appropriate osmotic pressure but also electrolyte balance (Ekawasti et al., 2017). Piperazine citrate was used as a positive control. 
Piperazine citrate was used as a comparison which aims to determine the concentration of ethanolic extract of raw kepok banana peel which is effective as an anthelmintic. Piperazine citrate is well known as the drug of choice in the treatment of ascaridiasis (Latifah, 2019). The mechanism of action of piperazine citrate is to block acetylcholine at the neuromuscular junction site, then causing paralysis in parasitic worms (Subekti et al., 2013).

Based on the results of the study, ethanol extract of kepok banana peel with a concentration of $75 \%$ resulted in the highest number of $A$. galli mortality rate compared than concentrations of $25 \%$ and $50 \%$. These results are in accordance with what Asmaydo et al. (2019) who stated that the higher the concentration used for treatment, the faster the solution has effectiveness in parasite worm elimination. The to hours of in vitro treatment shows the highest mortality rate. This is because the longer of the duration, the direct contact that occurs between $A$. galli worms with the active compounds of raw kepok banana peel extract also becomes longer, so that more active compounds are absorbed by the worms (Jannah et al., 2017). From data processing, it is known that there is an interaction between the administration of extracts with various levels of concentration and the duration of immersion against the mortality rate of $A$. galli. Those results were in accordance with the study of Jannah et al. (2017) who states that the longer duration and the higher the concentration of treatment potentially affect the mortality rate of parasite worms.

Ethanol extract of raw kepok banana peel has been proven to have active compounds as anthelmintics, namely alkaloids, saponins, flavonoids and tannins (Hasma and Winda, 2019). Anthelmintic are a compounds that play role to eliminate or remove worms from the digestive tract or the organs and tissues of host which used as parasite predilection (Simamora, 2011). In parasitic worms, alkaloids have main activity on the nervous system that can stop nerve cell impulses, then causing paralysis in $A$. galli (Utami, 2017). According to Alaydrus (2016), saponin compounds have an anthelmintic effect by inhibiting the mechanism of cholinesterase enzyme. The cholinesterase enzyme is inhibited by preventing the enzyme from hydrolyzing acetylcholine, as a result, acetylcholine will slightly accumulate (Siswandono, 2016). According to Himah (2017), the accumulation of acetylcholine was lead to chaos effect in the impulses delivery system to muscle cells. This situation causes the impulses to be discontinued, then causeing muscles to spasm condition, and eventually paralysis then lead to death. Several flavonoid compounds that have been studied have anthelmintic activity, such as flavones (2-phenyl chromone) which have anthelmintic activity against nematodes and affect glycogen metabolism (Ridwan et al., 2020). Tannin compounds have anthelmintic efficacy by interfering with energy formation through inhibit oxidative phosphorylation and bind to glycoprotein-free proteins in the cuticle which can cause death of parasitic worm (Parvathy et al., 2012).

\section{Conclusions}

The concentration level of raw kepok banana ethanol extract had an effect on the mortality rate of $A$. galli. Observation period also have significant effect against the mortality rate of $A$. galli. There was an interaction between the various doses with the duration of observation against the mortality rate of $A$. galli. In present study, the highest results in mortality rate of $A$. galli was recorded at $95.8 \%$ with the concentration and duration of treatment were recorded at $75 \%$ and 10 hours respectively.

\section{References}

Ahmad, S. N. 2014. Kajian Efektivitas Pemberian Obat Cacing Herbal Terhadap Performa Sapi Potong. Prosiding Seminar Nasional "Inovasi Teknologi Pertanian Spesifik Lokasi”. Banjarbaru. 503-509.

Alaydrus, S. M. F. G. 2016. Efek Anthelmintik Infusa Biji Kapuk (Ceiba pentranda L.) terhadap Cacing Ascaris suum Betina Secara In Vitro [Skripsi]. Universitas Kristen Maranatha. Bandung.

Asmaydo, D., I. S. Hamid, M. Yunus, Kusnoto, M. Sukmanadi dan E. Suprihati. 2019. Aktivitas Anthelmintika Ekstrak Etanol Daun Afrika (Vernonia amygdalina) terhadap Mortalitas Fasciola gigantica secara In Vitro. J. Parasite. Sci. 3(1): 15-18.

Butaye, P., L. A. Devriese, and F. Haesebrouck. 2003. Antimicrobial Growth Promoters Used in Animal Feed: Effects of Less Well Known Antibiotics on Gram-Positive Bacteria. Clin. Microbiol. Rev. 16(2): 175188. 
Dinastutie, R., S. Y. S. Poeranto dan D. Y. N.Hidayati. 2015. Uji Efektifitas Antifungal Ekstrak Kulit Pisang Kepok (Musa acuminata $x$ balbisiana) Mentah Terhadap Pertumbuhan Candida albicans Secara InVitro. Majalah Kesehatan FKUB. 2(3): 173-180.

Djunaidi, I.H., M. L. Amalia dan O. Sjofjan. 2014. Efek Penggunaan Tepung Kulit Pisang Tanduk Sebagai Pengganti Tepung Jagung Terhadap Kualitas Internal Telur Burung Puyuh (Coturnix - Coturnix Japonica). Fakultas Peternakan, Universitas Brawijaya. Malang.

Hasma, H. dan W. Winda. 2019. Identifikasi Senyawa Metabolit Sekunder Ekstrak Kulit Pisang Kepok (Musa paradisiaca L.) dengan Metode KLT. Jurnal Kesehatan Menarang. 5(2): 125-131.

Hidayat, C. 2012. Pengembangan Produksi Ayam Lokal Berbasis Bahan Pakan Lokal. Wartazoa. 22(2): 85-98.

Himah, S. A. 2017. Aktivitas Hepatoprotektor Tepung Kedelai (Glycine max L.) terhadap Peningkatan Kadar MDA Hati Tikus Wistar Jantan yang Diinduksi Diazinon [Skripsi]. Fakultas Kedokteran. Universitas Jember.

Istyan, Y. O. 2015. Gambaran Histopatologi Duodenum Ayam Pedaging yang Diinfeksi Ascaridia galli dengan Daun Pare (Momordica Charantia) [Skripsi]. Fakultas Kedokteran Hewan. Universitas Airlangga.

Jannah, R. N., S. M. Sosiawati, S. Chusniati, Kusnoto, R. Sugihartuti dan S. Sigit. 2017. Potensi Anthelmintik Ekstrak Biji Mangga Gadung (Mangifera indica L.) terhadap Cacing Mecistocirrus digitatus In Vitro. J. Parasite. Sci. 1(2): 59-64.

Kaplan, R.M. 2004. Drug Resistance in Nematodes of Veterinary Importance. A status Report. Trends in Parasitol. 20(10): 477-481.

Latifah, S. A. N. 2019. Effectiveness of Pumpkin Seed (Cucurbita Moschata) Ethanol Extract on Mortality of Ascaridia galli In Vitro. [Thesis]. Faculty of Veterinary Medicine. Universitas Airlangga. Surabaya.

Max, R.A., Dawson, J.M., Wakelin, D., Buttery, P.J., Kimambo, A.E., Kassuku, A.A. dan Mtenga, L.A. 2002. Effect of Condensed Tanin Extracts on Gastrointestinal
Nematodes of Small Ruminants. In: Goat keepers cluster projects: project $\mathrm{R}_{7424}$. Sokoine University of Agriculture. Morogoro. Tanzania.

Meritha, R. 2019. Daya Anthelmintika Ekstrak Etanol Buah Pare (Momordica charantia L.) terhadap Cacing Fasciola gigantica secara In Vitro. [Skripsi]. Fakultas Kedokteran Hewan. Universitas Airlangga.

Mubarokah, W. W., Kurniasih, W. Nurcahyo dan J. Prastowo. 2019. Pengaruh In Vitro Infusa Biji Buah Pinang (Areca catechu) terhadap Tingkat Kematian dan Morfometri Ascaridia galli Dewasa. Jurnal Sain Veteriner. 37(2): 166-171.

Ningsih, W. D., T. Suteky dan Dwatmadji. 2013. Pengaruh Ekstrak Melastoma malabathricum terhadap Fisiologi pada Kambing Kacang yang Terinfestasi Haemonchus contortus. Jurnal Sain Peternakan Indonesia. 8(1): 25-34.

Ozaraga, B. P., M. S. I. Ozaraga and M. B. Barrios. 2015. Ethnobotanical Dewormer Composition for Free Range Native Chickens. Mindanao Journal of Science and Technology. 13: 12-19.

Pabala, M. F. 2016. Prevalensi dan Intensitas Infeksi Cacing Ascaridia galli pada Ayam Buras di Wilayah Bukit Jimbaran, Bandung [Skripsi]. Fakultas Kedokteran Hewan. Universitas Udayana.

Pappa, S., A. W. Jamaluddin dan A. Ris. 2019. Kadar Tanin pada Kulit Buah Kakao (Theobroma cacao L.) Kabupaten Poliwalimandar dan Toraja Utara. Cakra Kimia (Indonesian E-Journal of Applied Chemistry) 7(2): 92-101.

Parvathy, N. G., R. Padma, V. Renjith, K. P. Rahate and T. S. Saranya. 2012. Phytochemical Screening and Anthelmintic Activity of Methanolic Extract of Imperata cylindrica. Int. J. Pharm. Pharmaceut. Sci. 4(3).

Ridwan,Y., F. Satrija dan E. handharyani. 2020. Aktivitas Anticestoda In Vitro Metabolit Sekunder Daun Miana (Coleus blumei. Benth) terhadap Cacing Hymenolepis microstoma. Jurnal Medik veteriner. 3(1): 31-37.

Simamora, N. 2011. Performa Produksi dan Karakteristik Organ Dalam Ayam 
Kampung Umur 12-16 Minggu yang Diinfeksi Cacing Ascaridia Galli dan Disuplementasi Ekstrak Daun Jarak Pagar (Jatropha Curcas Linn) [Skripsi]. Fakultas Peternakan. Institut Pertanian Bogor.

Siswandono, S. 2016. Kimia Medisinal 2 Edisi 2. Airlangga University Press. Surabaya.

Soulsby, E. J. L. 1986. Helminths, Arthropods and Protozoa of Domesticated Animals. The English Language Book Society, Bailliere Tindall, London. p. 163-5.

Subekti, S., S. Koesdarto, S. M. Sosiawati dan Kusnoto. 2013. Buku Teks Helminthiasis Veteriner. Global Persasa press. Surabaya.

Suhendra, C. P., I. W. R. Widarta dan A. G. I. S. Wiadnyani. 2019. Pengaruh Konsentrasi Ekstrak Etanol terhadap Aktifitas Antioksidan Ekstrak Rimpang Ilalang (Imperata cylindrical (L) Beauv.) pada Ekstraksi Menggunakan Gelombang Ultrasonik. Jurnal Ilmu dan Teknologi Pangan. 8(1): 27-35.
Tiwow, D., W. Bodhi dan N. S. Kojong. 2013. Uji Efek Antelmintik Ekstrak Etanol Biji Pinang (Areca catechu) Terhadap Cacing Ascaris Lumbricoides dan Ascaridia Galli Secara In Vitro. Jurnal Ilmiah FarmasiUnsrat. 2(2): 76-80.

Utami, R. P. 2017. Aktivitas Anthelmintik Ekstrak Etanol Daun Meniran (Phyllanthus niruri L.) Terhadap Cacing Ascaridia Galli Secara In Vitro [Skripsi]. Fakultas Kedokteran. Universitas Tanjungpura. Pontianak.

Wulandari, Y. 2016. Uji Efek Antipiretik Infusa Batang Brotowali (Tinosporacrispa (l.) Miers) pada Tikus Putih Jantan Galur Wistar yang Diinduksi Vaksin DPT [Skripsi]. Fakultas Kedokteran. Universitas Muhammadiyah Surabaya. Surabaya.

Zalizar, L. dan I. D. Rahayu. 2001. Pengaruh Penggunaan Larutan Minyak Kayu Putih terhadap Penampilan Produksi Ayam Lurik Penderita Parasit Cacing. J. Agritek. 9(2): 874-879. 